\title{
Graduates Perception on Job Search: A Critical Review
}

\author{
Sumi Maharjan
}

Quest International College, Pokhara University, Nepal.

sumimaharjan77@gmail.com

Received:27 Sept, 2019

Revised: 25 Nov, 2019

Accepted: 17 Dec, 2019

Published: 28 Jan, 2020

How to cite this paper: Maharjan, $S$. (2019). Graduates perception on job search: A critical review. Quest Journal of Management and Social Sciences, 1(2), 308-317.

Copyright (C) 2019 by authors and Quest Journal of Management and Social Sciences

This work is licensed under a Creative Commons Attribution-NonCommercial-NoDerivatives 4.0 International License.

https://creativecommons.org/licenses/ by-nc-nd/4.0/

\begin{abstract}
Background: The impact of the increased popularity of the internet as a platform to search for jobs may benefit every job seeker as an alternative to generate employment opportunities. Graduates that emphasize on general skills have a higher likelihood of disparity while searching for jobs.
\end{abstract}

Objective:This paper explores graduates' perceptions on the knowledge of how to search for jobs from relevant sourcesr.

Methods: The theoretical review focuses on job search strategies, job choices and job accessibility through different sources, highlights the usefulness of job portals for job seekers to find the right job as per their skills and requirements. The existing literature has observed that many job search behaviors through different sources has been performed and these behaviors indicate that awareness level affects job seekers' intentions to apply for jobs. Empirical studies indicate that the choice of job search by graduates match between a worker's education and job offered. General skills have a higher likelihood of mismatch at job searches in different countries.

Findings: Still in many developing countries, due to lack of awareness of job portals, people are not getting the right jobs and alternatives of their current jobs by different sources.

Conclusions: A comprehensive study on applicability of the internet job search is useful for employers, considering the introduction of new graduate recruitment programmers. It is also useful for those wishing to improve their existing ones as well as for institutions of higher education, to reconsider the type of knowledge and skills they provide in order to prepare their students for the real world of work.

Implications: Graduates require proper awareness on job search sites and the concerned industry should focus on it as well.

Keywords: graduates perception, recruitment selection, higher education, job search skills, internet recruitment, employment services, information searches

Paper Type: Review Paper

JEL Classification: M10, O32, O33, I21 


\section{Introduction}

The impact of the increased popularity of the internet as a job search tool may benefit every job seeker (Suvankulov et al., 2012). This is because this behavior, through which effort and time are spent, acquires information about labor market alternatives and generates employment opportunities (Boswell, 2006) must faster as job portals provide fast, easy and systematic services to job seekers (Brencic and Norris, 2008). On the other hand, Branine (2008) argued that graduates initially have high and unrealistic expectations about job prospects and job market in recruitments and selections, whereas outcomes show that employers specifically expect education to be technology-based knowledge and skills in job searching (Hirudayaraj and Baker, 2018). On the other hand, graduates who explore the expectations according to real perspectives accrued the knowledge and skills in a preliminary management course, understand that they are required to have real-world skills and work readiness (Chavan \& Carter, 2018).

Robst (2007) explained that the graduates that emphasize on general skills have a higher likelihood of being mismatched at job searches. Also Jain and Bhatt (2015) claim that job mismatching can differ mainly across gender and age of prospective employees. In public and private sectors, applicants are being perceived significantly differently by the potential employers depending on branding factors. Employers have to build an attractive reputation and brand value in the job market so as to attract and retain the best talents. However, Virga and Rusu (2018) found that employed job seekers, namely, people with different personality traits maybe differently motivated to search for alternative employments. Employers' expectations from time to time as a means to determine the current and near-term knowledge and skills needed within organizations to address HRD activities and projects (Hirudayaraj and Baker, 2018). E-recruitment is an effective way for job seekers and employers to maintain competitive edge in the job market as job seekers can apply for multiple jobs in less time with low cost (Khan et al., 2013).

Individual characteristics of job seekers, not only on their daily job search activities and outcomes but also on their daily psychological well-beings, show the effects of recent university graduates individual characteristics like conscientiousness, self-esteem, proactive personality, job search self-efficacy, and job search clarity on daily job search behavior, daily job search effort, and daily psychological well-being, as well as on job search outcomes that is number of job interviews, number of job offers, and job acceptance (Georgiou et al., 2012).The importance of personality trait for matching the career choices in new candidates shows people who are more calm, relaxed and emotionally stable are more likely to be successful in public sector organizations (Hussain et al., 2012)

Comparisons to traditional employment channels (newspapers, friends and agencies), online job portals are able to provide a wider range of choice as well as increasingly more advanced tools to evaluate the suitability of a job for job seekers (Kurekova et al., 2015). Self-efficacy, intention and intensity gradually decline over time as a result of a number of unsuccessful job search attempts. Therefore, in addition to setting employment goals, university career advisors can develop (Wierik et al., 2015) the engagement in various activities 
organized by the university, such as development of the database of potential employers, participation in on-campus job fairs or attending workshops on how to develop effective resumes, may help to guide students not just along the path of goal clarification, but along the job search process (Yizhong et al., 2016).

New resource-based views affect the growing importance of people as part of organizations and this puts resources equal to products (Wernerfelt, 1984) and human capital becomes the source of competitive advantage in the world of business (Barney, 1991).The talent-employer relationship should be understood as an equal partnership in which needs of both should be mutually satisfied. A better knowledge of applicants' reactions to the use of SNWs, whether professional or recreational, when they are used for assessing candidates seeking a job, promotes a HR administrator's critical reflection in order to improve their use (Aguadoet al., 2016)

The candidates as potential customers, partners, and future employees regardless of their current experience level or fit within their company (Miller-Merrell, 2016) provide, positive results, not only conflicts for the organization. Understanding this aspect of job seekers behaviors can play important roles in the implementation HR policies. The leaders, managers and HR experts have to prepare for these challenges and this area has recently attracted the attention of scholars (Olsovska et al., 2016). Intergeneration of communication and information and sharing their techniques of generation $\mathrm{Z}$ are very different from the previous generations and it may lead to a lot of conflicts and give rise to a misunderstanding, if not systematically understood (Dill, 2015).

High levels of autonomy are associated with a major sense of self-efficacy in relation to seeking information on career opportunities and engaging in job searching activities. Moreover, autonomy is negatively related to difficulties in the career decision-making process at its beginning. For instance, Guay et al. (2006) showed that young adults with lower levels of autonomy were at risk of experiencing chronic career indecision. This paper mainly aims to explore the perceptions of graduates as job seekers on search for jobs.

The remainder of the study is structured as follows. Section 2 gives an overview of literature and Section 3 describes the methodology used in the study. Section 4 presents the findings. Section 5 of the paper concludes the study.

\section{Review of Literature}

\section{Traditional vs Modern Recruitment}

Employers across the globe use traditional recruitment methods. The simplicity and familiarity of using these methods such as paper-based job postings, internal hiring, referrals and word-of-mouth are still popular choices amongst lots of hiring professionals today. However, these methods for hiring and recruitment are simply not enough to acquire best talents in an era of technology. Instead, a more modern i.e., slightly updated approach enables hiring teams to make more effective and efficient hiring decisions with the assistance of technology. This process is more effective for getting the right person because of less dependency on human input while making hiring decisions and completing hiring tasks. One may argue 
which methods of recruitment are the best, but overtime both have advantages in helping organizations hire the best possible candidates. When it comes to recruitment, organizations around the world have reaped the benefits of the traditional recruitment methods which have served them well and delivered employees which have played a key role in defining their organizations. The traditional recruitment methods are local paper advertisement, local employment office postings and internal hiring. The 21st century has seen a significant rise in technology and this rapid growth in technology has influenced recruitment methods and made a difference in landing candidates for organizations all over the world. The power of social media and job portals are the modern trends of getting right persons for employers.

\section{Students' Knowledge/ Perception on Search for Jobs}

Though students are from multicultural, multiethnic and multilingual class (Paudel et al., 2018) career perceptions are their ultimate goals for which an individual sets out to achieve either in current profession or desired profession in future. It clearly defines as to what an individual needs from his work. It is the path that an individual wants his/her career to follow. The need for vocational guidance and counseling varies across cultures. (Ramachandran, 2012).The career perceptions of students revealed that most of the students preferred teaching/medicine as the proposed career because of better working condition. Vocational guidance helped them to choose the career to a great extent.

\section{Theory on Search for Jobs}

The innovation has changed the way job seekers look for occupations and managers find qualified representatives. While businesses still promote employment opportunities through conventional publicizing mediums, traditional and modern methods like nearby papers and magazines, today managers and job seekers swing to online employment gateways to discover work matches. Online occupation gateway offers the job seekers a platform for finding privileged opportunities for their employment as per their applications. A job portal, also known as a career portal, is a modern name for an online platform that helps applicants find jobs and aids employers in their quest to locate ideal candidates. It contains direct solicitations for employment. Most work gateways enable the job seekers to apply for occupations online immediately, or they connect the applicants with the prospective jobs. A job portal might provide additional information, such as a company's website or a direct contact numbers of the department of human resource (Kristine Tucker, 2018).

\section{Empirical Studies}

Empirical research is a way of gaining knowledge by means of direct and indirect observations or experience. Empirical evidence can be analyzed quantitatively or qualitatively. It is the review of previous studies that relate or argue with the study being conducted at present. It can further be said as systematic identification, location and analysis of documents containing information related to a research problem under investigation. The empirical review has been done on search for jobs, sources, behaviors and methods related to different countries. It helps to find the gap between previous studies and the present one and need of effectiveness of search for jobs in developing countries like Nepal. 
Table 1: Empirical Review

\begin{tabular}{|c|c|c|c|c|c|}
\hline Authors & Study & Country & Method & Result/Findings & $\begin{array}{l}\text { Conclusion/ } \\
\text { Recommendation }\end{array}$ \\
\hline $\begin{array}{l}\text { Ng and } \\
\text { Burke } \\
(2006)\end{array}$ & $\begin{array}{l}\text { The next } \\
\text { generation at } \\
\text { work - } \\
\text { business } \\
\text { students' } \\
\text { views, values } \\
\text { and job search } \\
\text { strategy }\end{array}$ & Canada & $\begin{array}{l}\text { Internet- } \\
\text { based survey }\end{array}$ & $\begin{array}{l}\text { Students with higher } \\
\text { abilities also reported } \\
\text { similar characteristics } \\
\text { and preferences to those } \\
\text { of cooperative students. } \\
\text { These } \\
\text { characteristics are } \\
\text { important because } \\
\text { they have been linked } \\
\text { to greater recruitment } \\
\text { success }\end{array}$ & $\begin{array}{l}\text { Strategies in } \\
\text { combination canassist } \\
\text { employers with } \\
\text { greater recruitment } \\
\text { success and long- } \\
\text { term organizational } \\
\text { performance. }\end{array}$ \\
\hline $\begin{array}{l}\text { Ford et.al } \\
(2008)\end{array}$ & $\begin{array}{l}\text { Web } \\
\text { searching by } \\
\text { the "general } \\
\text { public": an } \\
\text { individual } \\
\text { differences } \\
\text { perspective }\end{array}$ & UK & $\begin{array}{l}\text { Sampling } \\
\text { Method }\end{array}$ & $\begin{array}{l}\text { Number of interactions } \\
\text { between individual } \\
\text { differences, the use of } \\
\text { different search } \\
\text { strategies, and levels } \\
\text { of perceived search } \\
\text { difficulty and success }\end{array}$ & $\begin{array}{l}\text { Better understanding } \\
\text { of factors affecting } \\
\text { searching may help } \\
\text { one to } \\
\text { develop more effective } \\
\text { search support, } \\
\text { whether in the form } \\
\text { of personalized search } \\
\text { interfaces and } \\
\text { mechanisms, adaptive } \\
\text { systems, training or } \\
\text { help systems }\end{array}$ \\
\hline $\begin{array}{l}\text { McKeown } \\
\text { and Lindorff } \\
(2011)\end{array}$ & $\begin{array}{l}\text { The graduate } \\
\text { job search } \\
\text { process } \\
\text { - a lesson in } \\
\text { persistence } \\
\text { rather } \\
\text { than good } \\
\text { career } \\
\text { management }\end{array}$ & Australia & $\begin{array}{l}\text { Qualitative } \\
\text { Method }\end{array}$ & $\begin{array}{l}\text { Major inconsistencies } \\
\text { between the viewpoints } \\
\text { of graduates and UCCs } \\
\text { regarding the } \\
\text { usefulness of UCCs, } \\
\text { as not only did most } \\
\text { graduates not use these } \\
\text { services, they were often } \\
\text { completely } \\
\text { unaware of them }\end{array}$ & $\begin{array}{l}\text { To develop strategies } \\
\text { for engaging students } \\
\text { in the career } \\
\text { seeking process early } \\
\text { in their studies, and } \\
\text { promote the availability } \\
\text { and utility of their } \\
\text { services }\end{array}$ \\
\hline $\begin{array}{l}\text { Suvankulov } \\
\text { et.al (2012) }\end{array}$ & $\begin{array}{l}\text { Job search on } \\
\text { the internet } \\
\text { and its } \\
\text { outcome }\end{array}$ & UK & $\begin{array}{l}\text { Probit and } \\
\text { Hausman- } \\
\text { Taylor IV } \\
\text { models }\end{array}$ & $\begin{array}{l}\text { Job seekers who used } \\
\text { the internet had a } \\
\text { shorter duration of } \\
\text { unemployment in both } \\
\text { Germany and South } \\
\text { Korea }\end{array}$ & $\begin{array}{l}\text { The internet is } \\
\text { beneficial and should } \\
\text { be a part of job search } \\
\text { efforts. }\end{array}$ \\
\hline $\begin{array}{l}\text { Jain and } \\
\text { Bhatt (2015) }\end{array}$ & $\begin{array}{l}\text { Employment } \\
\text { preference } \\
\text { of job } \\
\text { applicants: } \\
\text { unfolding } \\
\text { employer } \\
\text { branding } \\
\text { determinants }\end{array}$ & India & $\begin{array}{l}\text { Hypothetical } \\
\text { Method }\end{array}$ & $\begin{array}{l}\text { Choice for the majority } \\
\text { of potential employees } \\
\text { in both public } \\
\text { and private sector } \\
\text { organization }\end{array}$ & $\begin{array}{l}\text { To explore the } \\
\text { processes which } \\
\text { underlie the } \\
\text { organization choice } \\
\text { decision of prospective } \\
\text { applicant }\end{array}$ \\
\hline
\end{tabular}




\begin{tabular}{|c|c|c|c|c|c|}
\hline Authors & Study & Country & Method & Result/Findings & $\begin{array}{l}\text { Conclusion/ } \\
\text { Recommendation }\end{array}$ \\
\hline $\begin{array}{l}\text { Mowbray } \\
\text { et.al (2017) }\end{array}$ & \begin{tabular}{|l} 
Job search \\
information \\
behaviors: \\
An ego-net \\
study of \\
networking \\
amongst \\
young job- \\
seekers
\end{tabular} & UK & $\begin{array}{l}\text { Sample } \\
\text { choice and } \\
\text { description } \\
\text { Method }\end{array}$ & $\begin{array}{l}\text { Understanding of the } \\
\text { information behaviors } \\
\text { that } \\
\text { support the effective } \\
\text { mobilization of contacts } \\
\text { within social networks } \\
\text { during job search }\end{array}$ & $\begin{array}{l}\text { To develop a policy- } \\
\text { makers } \\
\text { whose remit includes } \\
\text { the employability of the } \\
\text { youth labor force. }\end{array}$ \\
\hline $\begin{array}{l}\text { Chavan } \\
\text { and Carter } \\
(2018)\end{array}$ & $\begin{array}{l}\text { Management } \\
\text { students - } \\
\text { expectations } \\
\text { and } \\
\text { perceptions } \\
\text { on work } \\
\text { readiness }\end{array}$ & Australia & $\begin{array}{l}\text { NViVO } \\
\text { Method }\end{array}$ & $\begin{array}{l}\text { The research outcomes } \\
\text { show that those } \\
\text { who held a part-time } \\
\text { job while studying } \\
\text { demonstrated a } \\
\text { better understanding } \\
\text { of the preliminary } \\
\text { management } \\
\text { subject matter taught } \\
\text { in class and obtained } \\
\text { better grades. }\end{array}$ & $\begin{array}{l}\text { Governments can } \\
\text { provide financial } \\
\text { incentives and } \\
\text { subsidies to } \\
\text { organizations providing } \\
\text { the above } \\
\text { services and working } \\
\text { cooperatively with } \\
\text { the universities to get } \\
\text { students work-ready. } \\
\text { Universities must raise } \\
\text { the educational } \\
\text { requirements over time } \\
\text { as jobs become more } \\
\text { complex }\end{array}$ \\
\hline $\begin{array}{l}\text { Hirudayaraj } \\
\text { and Baker, } \\
(2018)\end{array}$ & \begin{tabular}{|l|} 
HRD \\
competencies: \\
analysis of \\
employer \\
expectations \\
from \\
online job \\
postings
\end{tabular} & USA & $\begin{array}{l}\text { qualitative } \\
\text { analysis }\end{array}$ & $\begin{array}{l}\text { employers specifically } \\
\text { expect education } \\
\text { technology-based } \\
\text { knowledge and skills }\end{array}$ & $\begin{array}{l}\text { Educational programs } \\
\text { can use these findings } \\
\text { to inform curricular } \\
\text { decisions } \\
\text { related to knowledge } \\
\text { and skills to be taught } \\
\text { and practiced during } \\
\text { the preparation of L\&D } \\
\text { practitioners and } \\
\text { HRD professionals. }\end{array}$ \\
\hline
\end{tabular}

Similarly, several studies have shown that use of internet is common for search for jobs. Likewise, Ladkin and Buhalis (2016) indicate that it is crucial to provide a basis for understanding the impact of online and social media recruitment trends and issues in order to identify the perception of graduates on search for jobs.

\section{Conceptual Framework}

The internet held great potential for improving the channels of communication between employers and job seekers. Cappelli (2001) and Freeman (2002) provide a good narrative of such expected effects. The internet has significantly reduced the cost of obtaining job-related information for job seekers and the cost of the application process for employers (Feldman and Klaas, 2002) as well. The concern for employers is to process a large number of unqualified applicants. The trends and the future of social media in job searching for different positions are changing in present time (Kajanova et al., 2016). The effects of a number of individual characteristics on the behavior, effort, outcomes of search for jobs and on psychological well-being job seekers as well (Georgiou etal., 2012). 
Figure 1: Conceptual Framework

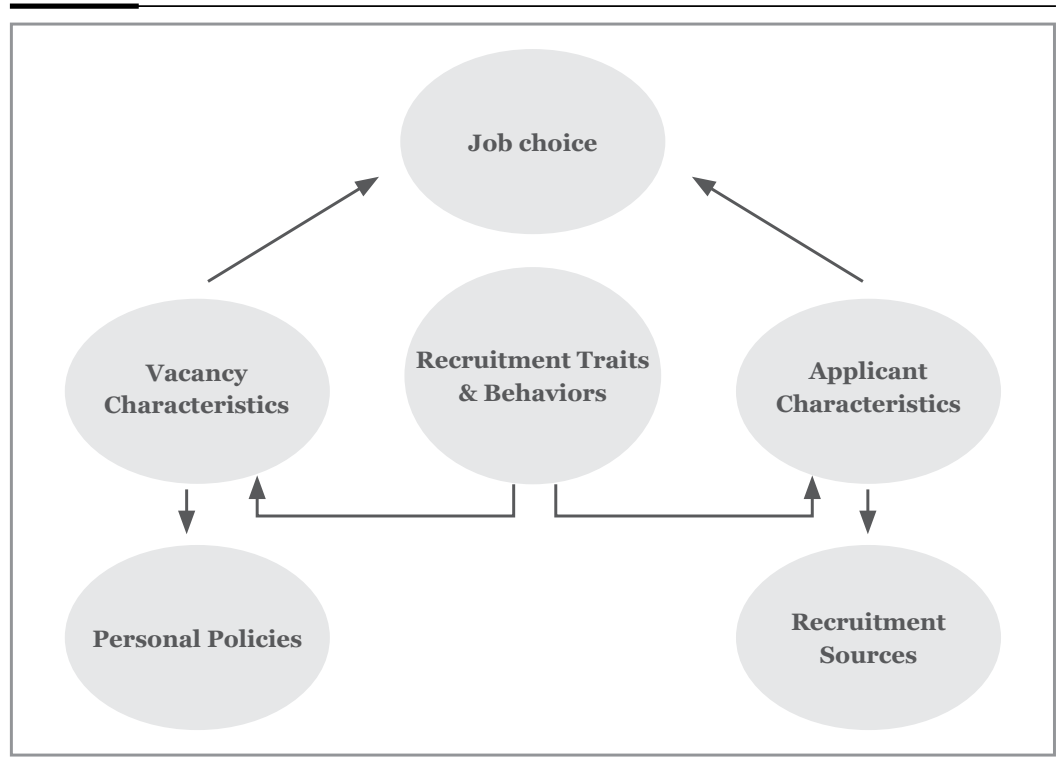

Jansen and Jansen (2005) examined the way job seekers use the internet and assess the effectiveness of such activity. Crispin and Mehler (1997), Bentley and Yoong (2000), Galanaki (2002) relate a larger sample and geography of applicants of potential applicants to a greater chance of finding a right person for the job. A large cohort of authors agree that major advantage of e-recruitment is an ability to reduce the duration of the recruitment process due to expedient job postings, faster applicant response, and faster resume processing.

We have designed the conceptual framework that describes the individual job choices to show job applying and searching characteristics of job seekers. The conceptual framework developed for the current study is modified from Sharma et al. (2011). Previous studies, reviewed in this paper, examined various types of search for jobs enabled the researcher understand its outcomes in different countries. The analysis shows the behavior and traits of people's needs and wants towards job expectations and reality of getting jobs through sources as per satisfaction. However, the studies show that search for jobs depends on skills, knowledge and capability and people have different perceptions toward their search for jobs using different methods of search for jobs. In addition, the review also revealed that only few job seekers are aware of search for jobs in the market.

Based on the empirical review carried out for this study, we identified vacancy characteristics, applicant characteristics, personal policies and recruitment sources as independent variables that shape the traits and behaviors of recruitment and graduates' behavior of job choice are identified as dependent variables for this study. The study also revealed that position, qualification required determine vacancy characteristics and the socio-demographic behavior, accesses to the internet, job search strategy and recommendation determine the characteristics of applicants.After finding the vacancy characteristics and applicant characteristics ultimately shape the perception of the graduates towards job portal. 


\section{Discussion}

The simplicity and familiarity of using traditional and modern methods such as paper-based job postings, internal hiring, referrals and word-of-mouth are still popular choices amongst lots of hiring professionals today (Crossely et al., 2006). These methods of recruitment are the best, but overtime both have their positive aspects in helping organizations hire the best possible candidates. Branine et al. (2008) point out that the top priorities for recruitment have shown higher percentage in recruiting/sourcing highly-skilled talent compared to the improving quality of hire, improving sourcing techniques and pipelining talent. The appropriate place could be a job center, a newspaper or trade journal, a local shop, a board outside the head office building, or the internet the job search (Mortensen, 2003). In their study Devkota and Phuyal (2017) found that 95\% of youth studying school to undergraduate levels have access to internet and $94 \%$ of them have mobile phones. It indicates job portal can play significant contributing role for the development of job search effectiveness. Hence, the diversity of jobs and workers should be taken into account when measuring job accessibility.

\section{Conclusion}

Thus, the important role of information in the labor market for both employee and employers is the influence of a general-purpose information and communications technology (ICT) system in order to lead accessing and disseminating the information. The uses of job portals are useful for job seekers to find the right jobs appropriate for their skills and requirements. The importance of job portal is to provide job opportunities to maximum people who are searching for jobs. Due to the lack of awareness of job portals many people are not getting right jobs, according to their need assessment, and alternative of jobs from various sources. Different job portals like merojob.com, jobjee.com, hamrojob.com, ramrojob.com; smartzob. com have been launched in Nepal. Similarly, different companies provide similar types of services but the gap has been observed that the expectations of job seekers and the requirements of companies do not often properly match. However, many job seekers are not satisfied with the information provided by the companies about the prospects of jobs because information provided in the job portals are not found as per the reality.

\section{Acknowledgement}

Earlier version of this paper has been presented at International Business Conference (IBC, 2019) in Mid-western University; Surkhet, Nepal dated 14th-15th July 2019.

\section{Conflict of Interest}

The author declares no conflict of interest in preparing this article.

\section{References}

Aguado, D., Rico, R., Rubio, V. J., \&Fernández, L. (2016). Applicant reactions to social network web use in personnel selection and assessment. Revista de PsicologíadelTrabajo y de lasOrganizaciones, 32(3), 183-190.

Barney, J. (1991). Special theory forum the resource-based model of the firm: origins, implications, and 
prospects. Journal of management, 17(1), 97-98.

Bentley, K., \& Yoong, P. (2000). Knowledge work and telework: an exploratory study. Internet Research, 10(4), 346-356.

Borgatti, S. P., Everett, M. G., \& Linton, C. (2002). Freeman. 2002. Ucinet for windows: Software for social network analysis.

Boswell, W. (2006). Aligning employees with the organization's strategic objectives: Out of 'line of sight', out of mind. The International Journal of Human Resource Management, 17(9), 1489-1511.

Branine, M. (2008). Graduate recruitment and selection in the UK: A study of the recent changes in methods and expectations. Career Development International, 13(6), 497-513.

Brencic, V., \& Norris, J. (2008). Online job boards as an employer recruitment tool. In World Congress on National Accounts and Economic Performance Measures for Nations, Arlington, CA, May (pp. 12-17).

Cappelli, P. (2001). Making the most of on-line recruiting. Harvard business review, 79(3), 139-148.

Chavan, M., \& Carter, L. (2018).Management students-expectations and perceptions on work readiness. International Journal of Educational Management, 32(5), 825-850.

Crispin, G., \& Mehler, M. (1997). Recruiting rockets through cyberspace. HR Magazine, 42(12), 72-77.

Crossley, C. D., \& s Highhouse, S. (2005). Relation of job search and choice process with subsequent satisfaction. Journal of Economic Psychology, 26(2), 255-268.

Devkota, N., \&Phuyal, R. K. (2017). An analysis of nepalese youth understanding level on climate change. Asian Journal of Economic Modelling, 5(3), 342-353.

Dill, K. (2015). 7 things employers should know about the gen z workforce, forbes magazin, 11.6. Retrieved March 16, 2016, from http://www.forbes.com/sites/ kathryndill/2015/11/o6/7-thingsemployers-should-know-about-the-gen-z-workforce/

Feldman, D. C., \& Klaas, B. S. (2002). Internet job hunting: A field study of applicant experiences with on-line recruiting. Human Resource Management: Published in Cooperation with the School of Business Administration, The University of Michigan and in alliance with the Society of Human Resources Management, 41(2), 175-192.

Ford, N., Eaglestone, B., Madden, A., \& Whittle, M. (2009). Web searching by the "general public": An individual differences perspective. Journal of Documentation, 65(4), 632-667

Galanaki, E. (2002). The decision to recruit online: A descriptive study. Career development international, 7(4), 243-251.

Georgiou, K., Nikolaou, I., Tomprou, M., \&Rafailidou, M. (2012). The role of job seekers' individual characteristics on job seeking behavior and psychological well-being. International Journal of Selection and Assessment, 20(4), 414-422.

Guay, F., Ratelle, C. F., Senécal, C., Larose, S., \&Deschênes, A. (2006). Distinguishing developmental from chronic career indecision: Self-efficacy, autonomy, and social support. Journal of Career Assessment, 14(2), 235-251. doi:10.1177/1069072705283975

Hirudayaraj, M., \& Baker, R. (2018). HRD competencies: analysis of employer expectations from online job postings. European Journal of Training and Development, 42(9), 577-596

Hussain, S., Abbas, M., Shahzad, K., \& Bukhari, S. A. (2012). Personality and career choices. African Journal of Business Management, 6(6), 2255-2260.

Jain, N., \& Bhatt, P. (2015). Employment preferences of job applicants: unfolding employer branding determinants. Journal of Management Development, 34(6), 634-652

Jansen, B. J., Jansen, K. J., \& Spink, A. (2005).Using the web to look for work: Implications for online job seeking and recruiting. Internet research, 15(1), 49-66.

Kajanová, H., Sedláček, M., Soósová, V. (2017), Attitudes of Young People to Job Searching through 
Social Media: Case of Slovakia, Economics and Sociology, 10 (1), 152-168.

Khan, N. R., Awang, M., \&Ghouri, A. M. (2013).Impact of e-recruitment and job-seekers perception on intention to pursue the jobs. Management \& Marketing, 11(1), 47-57.

Kureková, L. M., Beblavý, M., \& Thum-Thysen, A. (2015).Using online vacancies and web surveys to analyse the labour market: a methodological inquiry. IZA Journal of Labor Economics, 4(1), 18.

Ladkin, A., \&Buhalis, D. (2016). Online and social media recruitment: Hospitality employer and prospective employee considerations. International Journal of Contemporary Hospitality Management, 28(2), 327-345.

McKeown, T., \&Lindorff, M. (2011). The graduate job search process-a lesson in persistence rather than good career management?. Education+ Training, 53(4), 310-320.

Miller-Merrell, J. (2016), 5 Powerful Recruiting Trends in 2016, Retrieved from http://www.jobvite. $\mathrm{com} / \mathrm{blog} / 5$-powerful-recruiting-trends-in-2016/

Mortensen, D. (2003). Wage dispersion: why are similar workers paid differently?. MIT press.

Mowbray, J., Hall, H., Raeside, R., \& Robertson, P. J. (2018). Job search information behaviours: An ego-net study of networking amongst young job-seekers. Journal of Librarianship and Information Science, 50(3), 239-253

Ng, E. S., \& Burke, R. J. (2006). The next generation at work-business students' views, values and job search strategy: Implications for universities and employers. Education+ Training, 48(7), 478-492.

Olšovská, A., Mura, L., \&Švec, M. (2016). Personnel Management in Slovakia: Current Latent Issues. Mediterranean Journal of Social Sciences, 7 (2). 12-19

Paudel, U. R., Devkota, N., Ghale, B. A., \&Adhikari, K. (2018). Communication and gender in bachelor's degree students' adjustment process: A study in Kathmandu, Nepal. Journal of Education, Society and Behavioural Science, 27(4), 1-9.

Ramachandran, K. (2006). Indian family business: Their survival beyond three generations. Indian School Business, Hyderabad.

Robst, J. (2007). Education and job match: The relatedness of college major and work. Economics of Education Review, 26(4), 397-40.

Sharma, J. P., Bajpai, N., \& Holani, U. (2011). Organizational citizenship behavior in public and private sector and its impact on job satisfaction: A comparative study in Indian perspective. International Journal of Business and Management, 6(1), 67.

Suvankulov, F., Lau, M. C. K., \& Chau, F. H. C. (2012). Job search on the internet and its outcome. Internet Research. 22(3), 298-317.

te Wierik, M. L., Beishuizen, J., \& van Os, W. (2015). Career guidance and student success in Dutch higher vocational education. Studies in Higher Education, 40(10), 1947-1961.

Tucker, K. (2018). Advantages and disadvantages of rising college tuition. Retrieved from https://www. theclassroom.com/advantages-disadvantages-of-rising-college-tuition-13590847.html

Vîrga, D., \&Rusu, A. (2018). Core self-evaluations, job search behaviour and health complaints: The mediating role of job search self-efficacy. Career Development International, 23(3), 261-273

Wernerfelt, B. (1984). A resource-based view of the firm. Strategic management journal, 5(2), 171-180.

Yizhong, X., Lin, Z., Baranchenko, Y., Lau, C. K., Yukhanaev, A., \& Lu, H. (2017). Employability and job search behavior: A six-wave longitudinal study of Chinese university graduates. Employee Relations, 39(2), 223-239. 